\title{
EVALUATION OF REVERBERATION TIME IN THE CLASSROOM (CASE OF CLASSROOM AT DEPARTMENT OF ARCHITECTURE, UNIVERSITAS SEBELAS MARET)
}

\author{
ISWATI, Tri Yuni \\ Architecture Department, Sebelas Maret University, \\ Jalan Ir. Sutami 36A, Surakarta 57126, Indonesia \\ Email: yuniiswati@gmail.com/yuniiswati@staff.uns.ac.id
}

\begin{abstract}
This study took place in three rooms in one building, give and take the external conditions were relatively similar. The study aims to observe the level of acoustic comfort and suggest strategies to improve the acoustic comfort by modifying materials and dimensions of the materials. The modification is much needed in practice since the user critize the acoustical comfort of the room. The method applied was simply measuring the condition of the rooms using laser distance meter and sound level meter, taking notes on the characteristic of the material used, and developing simulation based on several modifications in materials and dimensions of the materials. The result of the simulation was then being compared to the standart of reverberation time. The conclusion of the study was made into three points: (1) the acoustic condition in the rooms are indeed not meeting the standart to ensure users' comfort, (2) the reverberation time is better when additional plasterboard ceiling are built, thus changing the rooms' dimension; and (3) the noise in each room is not significantly reduced even after the additional ceiling built. The simulation in this study was done through the help of Ecotect 2011.
\end{abstract}

Keywords: Acoustic; material; reverberation time.

\section{INTRODUCTION}

The study was based on the experience of researchers in the use of existing classrooms in Architecture and Urban Regional Planning and felt less comfortable in the the acoustic comfort. The idea of this research was to discover a low price and workable improvement to enhance the acoustic quality of the room. The output may still be less than ideal but, at least, users' experience will be better. Among ten classrooms in the departement of Arhitecture, three rooms were selected due to their worst acoutics comfort. Those three rooms were located in a close proximity to the Main Hall where informal activies of the students and other faculty members taking place. Two aspect of acoustic comfort were taken into account in this research, i.e. reverberation time and noise.

The first part of this paper presents definition of acoustic comfort and its components. The second part states the procedure taken in this study to ensure the accomplishment of the objectives. The later part potrays the simulation by Ecotect 2011 and concludes afterward.

\section{ACOUSTICS AND REVERBERATION TIME CALCULATION}

\section{Acoustics}

The Oxford Dictionary defines acoustics as "relating to sound or the sense of hearing". In the sphere of physics science relates to room, the term acoustics is used to explain the properties or qualities of a room or building that determine how sound is transmitted in it (Oxford University Press, 2017). In the classroom, there are three components to consider when studies of room acoustics are done as those components affect the information reception of the users. The three components are ambient noise, reverberation and signal to noise ratio (SNR).

Ambient noise, or sometimes called background noise, is prevailing noise level in a specified environment measured in the absence of the noise being studied (Ziobroski \& Powers, 2005). Ambient noise may be produced externally, for example the sound of rain, traffic, or operating powerplant outside the room. Internally, ambient noise may present by the noise from PC or laptop used, light blasts or simply users' conversation.

Signal to Noise Ratio (SNR) compares the signal (direct sound or prime sound) to the noise. Basically, SNR is used to understand the quality of the signal transferred to the users. Higher ratio is usually considered as better spesification because it is meant that the prime sound is louder than the noise (Altunian, 2016). Better level of SNR ensure better understanding of the captured audience especially when the audience need to give focus to the information. SNR are influenced by some factors, including sitting position of the audience, room dimension, and room materials. 
Reverberation is produced as the boundary surfaces of a room consist of a material which reflects the incident sound, the sound produced by a source inside the room - the direct sound - rebounds from one boundary to another, giving origin to the reflected sound (Hansen, tanpa angka tahun). The level of reverberation are measured to ensure that voices (the one that matters to be heard) can be heard clearly by the users. There are different level of ideal reverberation among different function of the room. Concert hall dan classroom present two considerably different reverberation level as the hum of the music may need to stay longer and more satiated in the concert hall. The level of reverberation time recommended for auditorium is 2 seconds in maximum, while in the classroom, ideal condition only allow 1 second. The level of reverberation time confirm the quality of room acoustics. In this study, it was calculated from the time that the sound decrease its volume to $60 \mathrm{~dB}$ belom the original volume of the prime voice.

Reverberation time can be calculated directly in the room where special equipment to calculate the reverberation time is installed. The other way would be calculating it manually using Sound Level Meter (SLM) and stopwatch. The procedure for manual calculation is setting the sound source and the SLM in the area of no obstruction. The source emits with volume higher than $60 \mathrm{~dB}$ in order to simplify the calculation when the sound drops in intensity as much as $60 \mathrm{~dB}$ as to prevent misexperiment due to the lack of voice to be identified.

For less active calculation, simulation of reverberation time can be done using the Sabin or Eyring formula. Sabin created a formula to calculate reverberation time in a room which is built using less sound absorbent materials, while Eyring formula are appropriately used for a room built using more sound absorbent materials.

Eyring formula is as follows:

$\mathrm{T}_{\mathrm{R}}=0.161 \mathrm{~V} /-\Sigma \mathrm{s} \cdot \operatorname{Ln}(1-\alpha)$

where:

$\mathrm{T}_{\mathrm{R}}$ ReverberationTime in second

$0.161=$ Constanta

$\mathrm{V} \quad=$ Volume $\left(\mathrm{m}^{3}\right)$

$\Sigma$ s $\quad=$ surface area $\left(\mathrm{m}^{2}\right)$

$\alpha \quad=$ absorption coefficient surface area

The Sabin formula is as follows:

$\mathrm{t}=0.161 \mathrm{~V} / \mathrm{A}$

where: $\mathrm{t}$ ReverberationTime in second

$\mathrm{V}$ is room volume $\left(\mathrm{m}^{3}\right)$

$\mathrm{A}=\Sigma \mathrm{s} . \alpha=$ is the total absorption of each of the boundary surfaces of the room $\left(\mathrm{m}^{2}\right)$

$\Sigma$ (surface area $\mathrm{x}$ coefficient of absorption).

For shaped space is not simple and has a variety of sound absorption coefficient on the surface then used a formula Mellington Sette;

$T_{R}=0.161 \mathrm{~V} /-\Sigma s_{n} \cdot \operatorname{Ln}\left(1-\alpha_{n}\right)$

where:

$0.161=$ Constanta

$\mathrm{V} \quad=$ Volume $\left(\mathrm{m}^{3}\right)$

$\Sigma \mathrm{s}_{\mathrm{n}} \quad=$ surface $\operatorname{area} \mathrm{n}\left(\mathrm{m}^{2}\right)$

$\alpha_{n} \quad=$ sound absorption coefficient surface area $n$

\section{Echo Control and Reverberation}

In certain circumstances, the general expectation is low level of reverberation, although in a room without any material obstruction, reverberation may still occur. When this appears to be the problem situation, the only intervention possible is to change the surface of the wall material forming the edges of the room. Intervention comes in the act of changing wall material from a high reflectivity to a low reflectivity material. The results showed that when the value of the total absorption in the room rose to twice the original value, then the undesirable sound reflections (or noise; Mediastika, 2006) can be decreased approximately $3 \mathrm{~dB}$. The rate of decline noise in space can be calculated using the following formula:

$\mathrm{NR}=10 \log (\mathrm{a} 2 / \mathrm{a} 1)$

where:

$\mathrm{NR}$ is a reduction noise obtained $(\mathrm{dB})$

a2 is the total absorption in the room after the redesign

a1 is the total absorption in the room existing

One note to be taken into consideration is that when using the logarithm to the division as in equation (4), then the formula can also be calculated in a way as follows.

$\mathrm{NR}=10(\log \mathrm{a} 2-\log \mathrm{a} 1)$.

As the level of absorption of every materials is very spcific to each frequency, it was important to calculate the NR for every frequency of prime sounds. To the calculation in paper simulation, NR of $20 \mathrm{~dB}$ may be achieved, but the real observation on the three rooms showed that NR $10 \mathrm{~dB}$ is the most effective level achieved. This undesirable result may come 
from the material's quality among other things. Room acoustic design is mainly about material selection when there is a small room for design modification. To achieve higher value of NR, intervention to the ceiling come as the most possible element of space to be taken into account. Generally, the ceiling is an element that is free from any other obstruction or divider, so it is a quite potential reflector of the prime sound. In the design of the classroom, the elements that must be considered are:

a. The shape and volume of the classroom

b. Factors that affects the hearing,

c. The influence of the geometry of the room views, namely horizontal cover and vertical sight lines, were good.

Reverberation time of the fully occupied classroom is ranging from 0.6 to 0.8 seconds at midfrequencies, and usually the volume of classrooms noise level is 55dB (Public Works Department, 2000)

\section{METHODOLOGY}

The procedure used in this study had seven steps. The steps are:

(1) room dimension measurement using laser distance meter

(2) noise measurements at several points in the room with sound level meter

(3) room material identification

(4) existing reverberation time calculation

(5) intervention simulations using Ecotect 2011

(6) redesigned room reverberation time calculation

(7) noise reduction calculation.

\section{RESULTS and DISCUSSION}

From the results of observations on the three classrooms and literature study, it was revealed that in existing design, the reverberation time is way substandard. When the intervention of ceiling addition is simulated, the prime voice was more focused and the reverberation time was better according to the standarts. This shows that the intervention of ceiling addition gave relust to optimum reverberation time.

$\mathrm{T}_{\mathrm{R}}=\frac{0.161 \mathrm{~V}}{\sum \mathrm{S} \alpha}$

$\mathrm{T}_{\mathrm{R}}=$ reverberation time; $0.161=$ constanta;

$\mathrm{V}=$ volume of room in $\mathrm{m}^{3}$;

$\sum \mathrm{S} \alpha=\mathrm{a}=$ the total absorption of the sound frequencies

$\mathrm{NR}=10 \log (\mathrm{a} 2 / \mathrm{a} 1) \mathrm{dB}$
$\mathrm{NR}=$ noise reduction

a1 = total sound absorption in the room existing conditions, Sabine

a2 = total sound absorption in the room after redesign, Sabine

The formula above was used to calculate reverberation time along two different condition, i.e. without ceiling as in existing condition and with ceiling as in redestgn condition. This study calculated two different strategies in intervention. Redesign \#1 added the ceiling, and redesign \#2 changed the material of the windows and doors. Table 1 presents the coefficient of different materials used in the added ceiling, while Table 2 presents the coefficient of the different materials used in the doors and windows. Table 3 informas the basic measurement of rooms dimensions. The simulations are presented in Tabel 5 through 7 for each room of 201A, $201 \mathrm{~B}$ and 202.

Room 202 reached the optimum level at $50 \%$ of occupancy. In this condition, the mean reverberation time calculated is $0.66 \mathrm{~s}$, and the optimum calculated was $0.63 \mathrm{~s}$. This is already within the ideal range of reverbation time for the classroom. Noise reduction was showing a small difference. This may caused by the lack of obervations through different frequencies as the Eyring or the Mellington Formula could not be used in this study.

\section{CONCLUSION}

The conclusion of the study have three points:

(1) the acoustic condition in the rooms are indeed not fullfil the standart to ensure users' comfort.

(2) the reverberation time is better when additional plasterboard ceiling are built (changing the rooms' dimension).

(3) the noise in each room is not significantly reduce even after the additional ceiling built.

Following the conclusion, the research recommends to construct ceiling by using specific material for acoustic comfort purposes. This will achieve ideal condition of reverberation time and noise reduction. As the specific material for acoustic comfort may cost a considerable amount of money, another alternative way is to use moneywise material. Although using alternative material may cost the aesthetic aspect of the room.

\section{REFERENCES}

Altunian, G. (2016). What is Signal to Noise Ratio? Accessed at https://www.lifewire.com/signalto-noise-ratio-3134701. 
Table 1. Coefficient Sound Absorption 1

\begin{tabular}{lcccccc}
\hline \multicolumn{1}{c}{ Materials } & \multicolumn{9}{c}{ Coefficients } \\
\cline { 2 - 8 } & $\mathbf{1 2 5 H z}$ & $\mathbf{2 5 0 H z}$ & $\mathbf{5 0 0 H z}$ & $\mathbf{1 k H z}$ & $\mathbf{2 k H z}$ & $\mathbf{4 k H z}$ \\
\hline Concrete Block, dense, painted & 0.10 & 0.05 & 0.06 & 0.07 & 0.09 & 0.08 \\
Acoustic Tile Suspended & 0.06 & 0.13 & 0.47 & 0.91 & 0.94 & 0.78 \\
Terazzo & 0.01 & 0.01 & 0.01 & 0.02 & 0.02 & 0.02 \\
Plywood Paneling, 3/8-inch thick & 0.28 & 0.22 & 0.17 & 0.09 & 0.10 & 0.11 \\
Brick, unglazed, painted & 0.01 & 0.01 & 0.02 & 0.02 & 0.02 & 0.03 \\
\hline
\end{tabular}

(Ecotech, 2011)

Table 2. Coefficient Sound Absorption 2

\begin{tabular}{lcccccc}
\hline \multicolumn{1}{c}{ Materials } & \multicolumn{9}{c}{ Coefficients } \\
\cline { 2 - 7 } & $\mathbf{1 2 5 H z}$ & $\mathbf{2 5 0 H z}$ & $\mathbf{5 0 0 H z}$ & $\mathbf{1 k H z}$ & $\mathbf{2 k H z}$ & $\mathbf{4 k H z}$ \\
\hline Door, Hollow Core, Plywood & 0.41 & 0.35 & 0.25 & 0.20 & 0.15 & 0.14 \\
Door, Solid Core, Pine Timber & 0.14 & 0.12 & 0.08 & 0.08 & 0.07 & 0.06 \\
Glass Sliding Door & 0.35 & 0.25 & 0.18 & 0.12 & 0.07 & 0.04 \\
Window, Single Glazed, Timber Frame & 0.14 & 0.09 & 0.02 & 0.00 & 0.00 & 0.00 \\
\hline
\end{tabular}

(Ecotech, 2011)

Table 3. The Identity of the Classroom

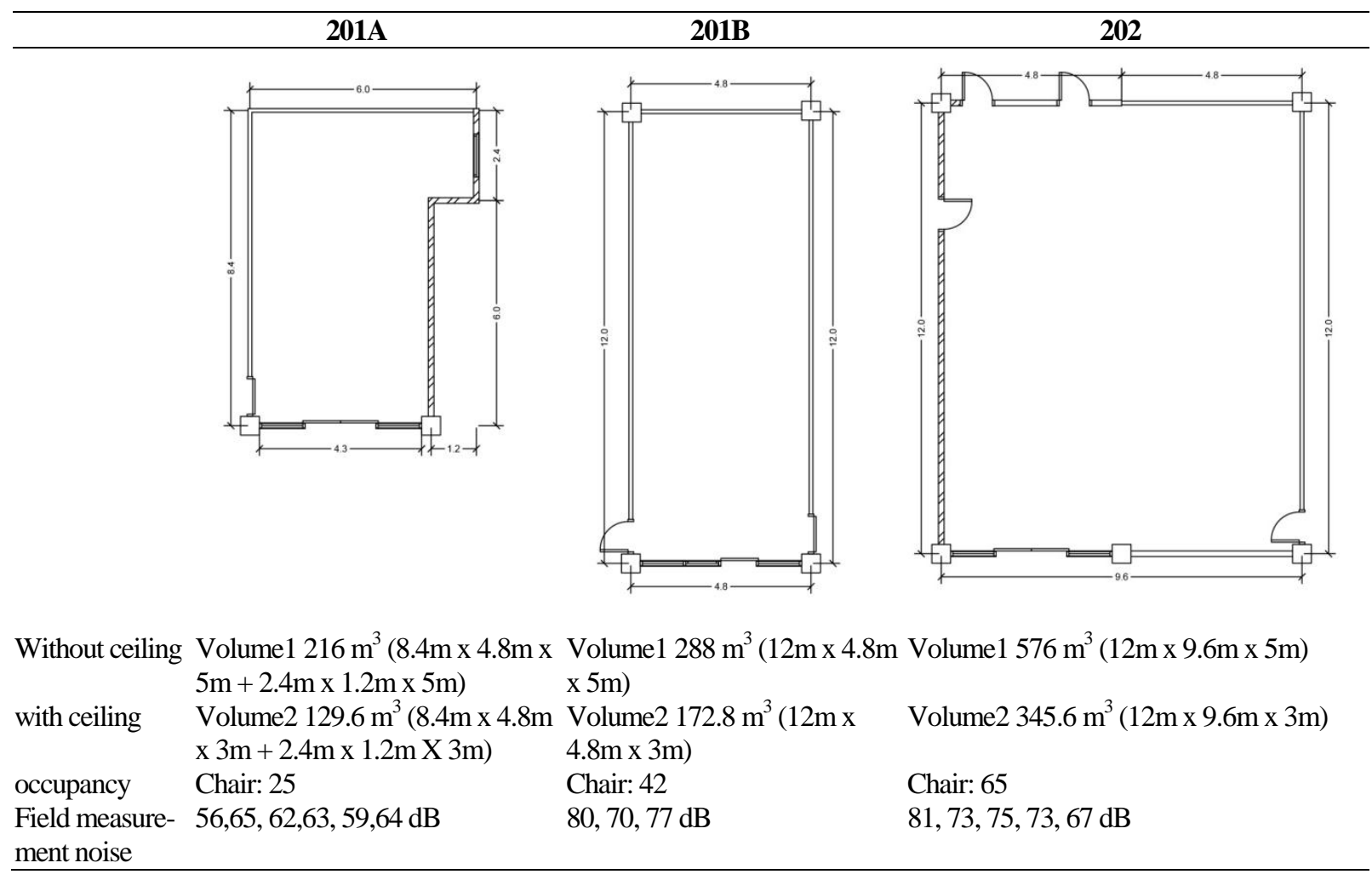


Table 4. Simulation the spread of sound at $201 \mathrm{~A}, 201 \mathrm{~B}, 202$

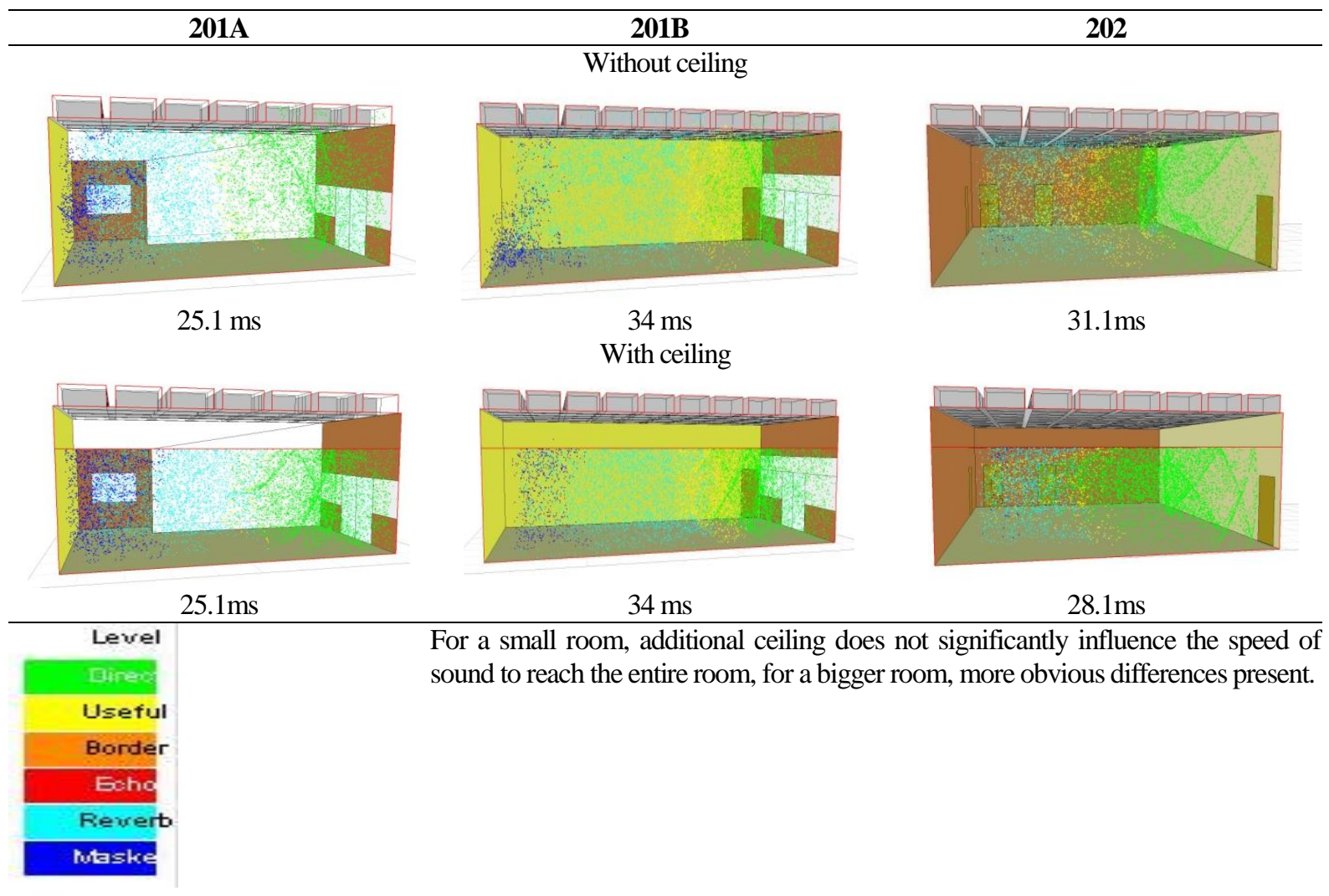

(Ecotect, 2011)

Table 5. Reverberation Time in 201A existing and after designing



Room $201 \mathrm{~A}$ reached the optimum rate at the $50-100 \%$ of occupancy, that the reverberation time $0.50 \mathrm{~s}-0.58 \mathrm{~s}$ approaching optimum reverberation time $0.53 \mathrm{~s}$. 
Departemen Pekerjaan Umum (2000). PEDOMAN Konstruksi dan Bangunan, Mitigasi Dampak Kebisingan Akibat Lalu Lintas Jalan. Jakarta: Departemen Pekerjaan Umum Accessed at http://www.pu.go.id/uploads/services/service2 0130717122457.pdf

Egan, M. D. (1988). Concepts in Architectural Acoustic. New-Jersey: McGraw-Hill.

Hansen, C. (tanpa angka tahun). Fundamental of Acoustics. South Australia: University of Adelaide. Accessed at www.who.int/occupational_health/publications/noise1.pdf

Joestiono, H. \& Asmoro, W.A. Desain Akustik Ruang Kelas Mengacu Pada Konsep Bangunan Hijau Kukuh Darmawan, ITS. Accessed at http://digilib.its.ac.id/public/ITS-paper-223462410105001-Paper.pdf

L'Espérance, A., Boudreau, A., Gariépy, \& Bacon, P. (2006). Noise reduction in day-care centresby reducing reverberation time Analyses and case studies. Subscription: 1-877-221-7046 accessed at http://www.irsst.qc.ca/media/documents/ pubirsst/R-463.pdf

Mediastika, C.E. (2006). Akustika Bangunan; Prinsip dan Penerapannya di Indonesia. Edisi 1. Jakarta: Penerbit Erlangga

Mediastika, C.E. (2006). Studi terhadap Reverberation time Pada ruang-Ruang pertemuan di UAJY (audiovisual, auditorium Kampus II dan auditorium kampus III) sebagai Indikator kualitas akustik ruangan. Unpublished

Oxford University Press. (2017) Oxford Dictionary Online version. Accessed at https://en.oxforddictionaries.com/definition/acoustic

Satwiko, P. (2009). Fisika Bangunan. Yogyakarta: CV Andi Offset

Ziobroski, D. \& Powers, C. (2005). Acoustics Terms, Definition, and General Information. GE Energy. Accessed at https://powergen.Gepower.com/content/dam/gepower-pgdp/global/ en_US/documents/technical/ger/ger-4248acoustic-terms-definitions-general-information.pdf 